\title{
New record of Zameus squamulosus (Chondrichthyes: Squaliformes: Somniosidae) in the Southern Gulf of Mexico
}

\author{
Eduardo Villalobos, Armando Martínez, Christian Lambarri and Héctor Espinosa*
}

\begin{abstract}
Zameus squamulosus is a somniosid shark with a patchy world-wide distribution that has been reported throughout the Atlantic, Indian, western, north, central and south-eastern Pacific Oceans. In the Northern Gulf of Mexico Zameus squamulosus is occasionally captured by longlines in deep waters off the coast of Florida, but until now there were no records of the species in the Southern Gulf of Mexico. Four specimens of Zameus squamulosus were collected in 2004 and 2009 on the continental slope of the Gulf of Mexico. Collections were made at depths of $698 \mathrm{~m}$ and $701 \mathrm{~m}$. These specimens constitute the first records of this species for the southern Gulf of Mexico and, as they were captured with bottom associated trawls, we infer that this species is more commonly found at the bottom ocean.
\end{abstract}

Keywords: New record, Southern Gulf of Mexico, Velvet Dogfish, Zameus squamulosus

\section{Introduction}

Zameus squamulosus was first described as Centrophorus squamulosus in 1877 by Günther from a female specimen collected in Japan. Barbosa du Bocage \& de Brito Capello 1864 reassigned this species to the genus Scymnodon. Later Jordan \& Fowler in 1903 designated this species as the type for their newly described genus Zameus, but Bigelow \& Schroeder (1957) concluded that Zameus was a junior synonym of Scymnodon. After morphological studies Taniuchi \& Garrick (1986) resurrected the genus Zameus and redefined Scymnodon as a monotypical genus from the North Atlantic. White et al. (2014) placed Zameus as a monotypical genus excluding the species Zameus ichiharai (Yano \& Tanaka 1984), now assigned to Scymnodon.

Zameus differs from Scymnodon, among other characters, in the presence of a medial tooth in the lower jaw (Fig. 1) and of dermal denticles with transverse ridges (Fig. 2). Recent molecular studies have confirmed the

\footnotetext{
* Correspondence: hector@unam.mx

Departamento de Zoología, Universidad Nacional Autónoma de México, Instituto de Biología, Colección Nacional de Peces, A.P. 70-153, D.F. 04510

Ciudad de México, Mexico
}

distinctiveness of the genus Zameus from Scymnodon, and place it closer to the genus Centroselachus (Naylor et al. 2012).

Zameus squamulosus is a poorly known somniosid shark that has a patchy world-wide distribution and has been reported throughout the Atlantic, Indian, western, north, central and south-eastern Pacific Oceans (Compagno et al. 2005; Akhilesh et al. 2013 and Ebert et al. 2014). This shark is epipelagic and bathypelagic, and is usually found off continental and insular slopes, on or near the bottom at depths of 550 to $1,450 \mathrm{~m}$, but also found well off the bottom at depths between 0 and $580 \mathrm{~m}$ in waters up to 2,000-6,000 m deep (Ebert et al. 2014).

In the Northern Gulf of Mexico Zameus squamulosus is occasionally captured by longlines in deep waters off the coast of Florida (Castro 2011), but until now there were no records of the species in the Southern Gulf of Mexico.

Four female specimens of Zameus squamulosus were captured during two separate collecting trips, conducted by the Research Vessel (RV) 'Justo Sierra' in the continental slope of Campeche and Veracruz. These records represent evidence of the presence of Zameus squamulosus in the Southern Gulf of Mexico. 

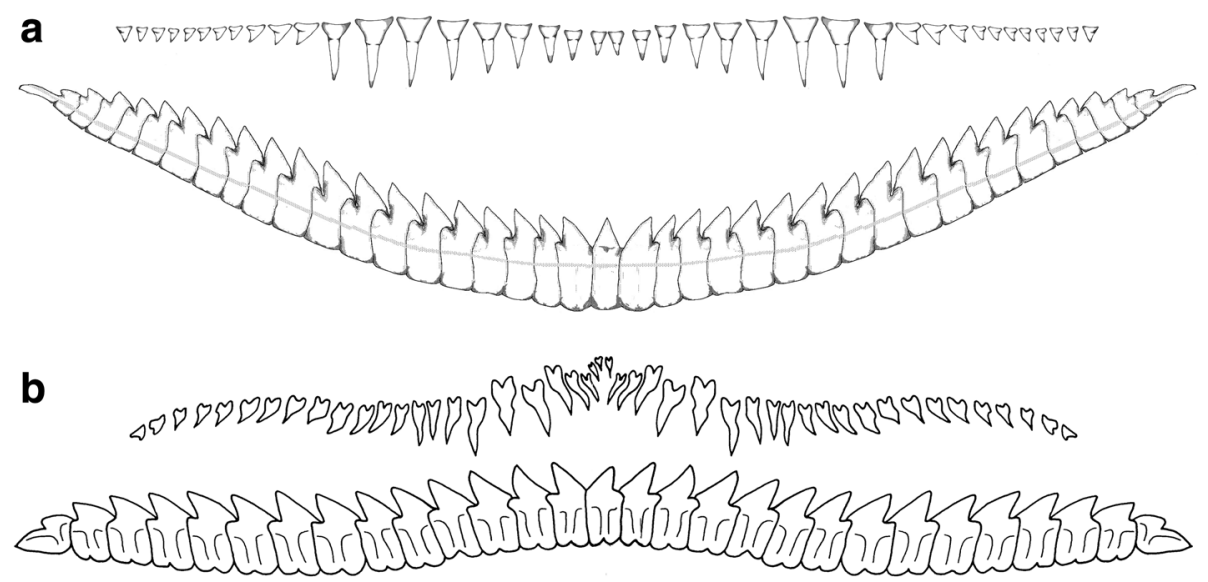

Fig. 1 Front view of teeth of Zameus squamulosus CNPE-IBUNAM 14608 (a) and Scymnodon ichiharai (b)

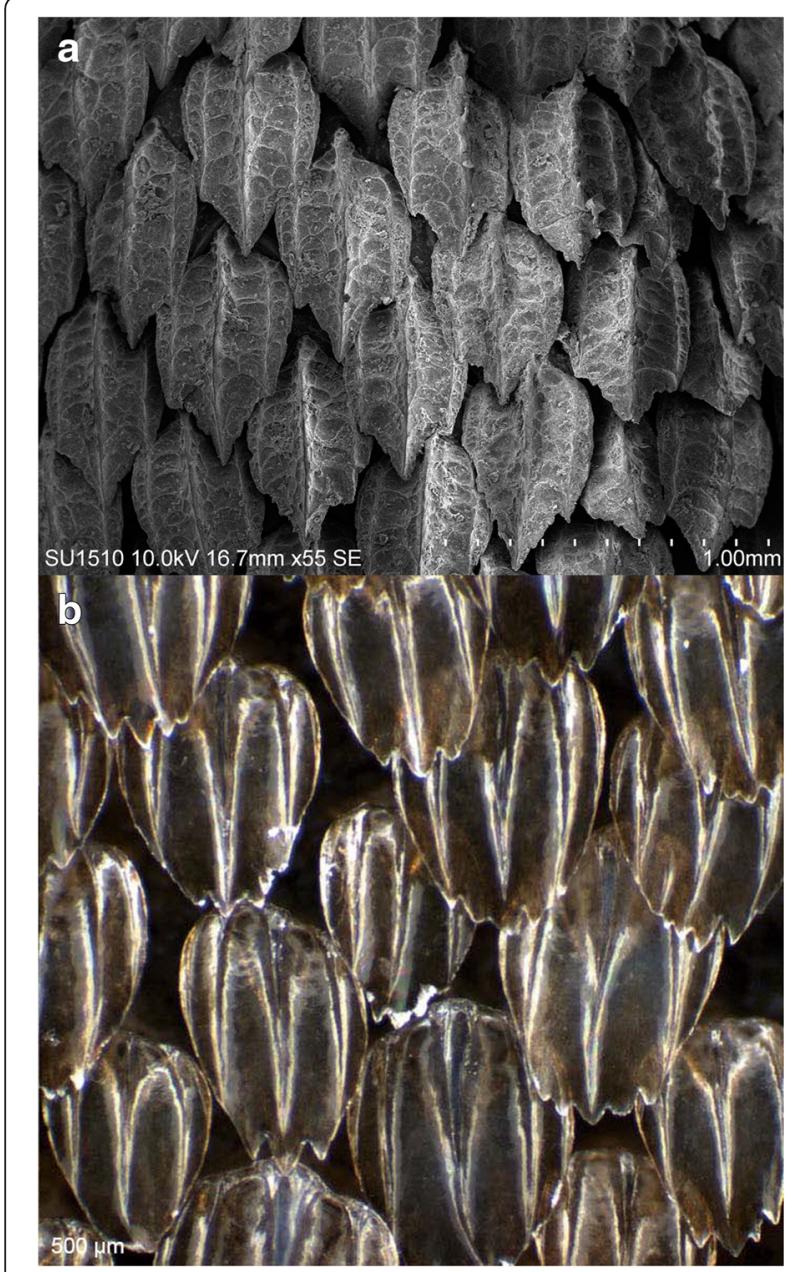

Fig. 2 Dermal denticles of Zameus squamulosus CNPE-IBUNAM 14608 (a) and Scymnodon ichiharai (b)

\section{Materials and methods}

The identification of the specimens was based on McEachran \& Fechhelm (1998), Castro (2011) and Ebert et al. (2013). Measurements (Table 1), were presented as a percentage of the total length (TL), were taken after Ebert \& Stehmann (2013) and were made in preserved specimens. Specimens were fixed in $10 \%$ formalin and subsequently preserved in $70 \%$ ethanol. All of the specimens were deposited in the Colección Nacional de Peces of the Instituto de Biología, Universidad Nacional Autónoma de México (CNPE-IBUNAM).

\section{Systematics}

Order SQUALIFORMES

Family SOMNIOSIDAE

Genus Zameus Jordan \& Fowler 1903

Zameus squamulosus (Günther 1877)

(Fig. 3)

\section{Results}

Two specimens (CNPE-IBUNAM 14608) were captured on 2004-07-27 at a depth of $689 \mathrm{~m}$, using a $12 \mathrm{~m}$ long, $9 \mathrm{~m}$ wide and $1.5 \mathrm{~m}$ tall semi-balloon otter trawl with a $6.35 \mathrm{~cm}$ mesh, during the Sigsbee VII project (22.41722 96.61110). The other two specimens (CNPE-IBUNAM 16547) were captured on 2009-08-23 at a depth of $701 \mathrm{~m}$, using a $12 \mathrm{~m}$ long, $9 \mathrm{~m}$ wide and $1.5 \mathrm{~m}$ tall semi-balloon otter trawl with a $6.35 \mathrm{~cm}$ mesh, during the COBERPES III project (18.97537-94.12077). Both campaigns were conducted over the continental slope in the Gulf of Mexico (Fig. 4.).

Specimens were identified as Zameus squamulosus in laboratory. All of them show the distinctive transverse 
Table 1 Morphometric and meristic data for the specimens of Zameus squamulosus deposited at the Colección Nacional de Peces of the Instituto de Biología, Universidad Nacional Autónoma de México (CNPE-IBUNAM). Measurements are expressed as a percentage of total length (\% TL)

\begin{tabular}{|c|c|c|c|c|}
\hline Measurements & CNPE-IBUNAM 14608 & CNPE-IBUNAM 14608 & CNPE-IBUNAM 16547 & CNPE-IBUNAM 16547 \\
\hline Total length & 330 & 290 & 270 & 250 \\
\hline Precaudal fin length & 80.3 & 73 & 76 & 80 \\
\hline Prenarial length & 1.5 & 1.3 & 2.1 & 2.8 \\
\hline Preoral length & 8.4 & 8.2 & 8.8 & 9.6 \\
\hline Preorbital length & 5.4 & 6.2 & 6.2 & 6.8 \\
\hline Head length & 22.7 & 24 & 22.2 & 24 \\
\hline Prepectoral fin length & 23 & 24.4 & 24 & 26 \\
\hline Prepelvic fin length & 60.6 & 60.3 & 59.2 & 60.6 \\
\hline Prefirst dorsal fin length & 43.7 & 49.3 & 38.8 & 40 \\
\hline Presecond dorsal fin length & 65.6 & 65.5 & 61.1 & 66 \\
\hline Interdorsal width & 19 & 16 & 17.4 & 18.4 \\
\hline Pectoral fin-pelvic fin space & 26 & 26.5 & 25.18 & 32 \\
\hline Eye length & 4 & 3.4 & 3.7 & 3.2 \\
\hline Eye height & 2.4 & 2.7 & 2.9 & 2.8 \\
\hline Mouth length & & 3.7 & 4.2 & 4 \\
\hline Mouth width & 7.2 & 6.8 & 7.4 & 7.7 \\
\hline Upper labial furrow length & 3.6 & 3.4 & 3 & 3.6 \\
\hline Lower labial furrow length & 2.1 & 2 & 2 & 2.4 \\
\hline First gill slit length & 2.1 & 1.9 & 2 & 2 \\
\hline Fifth gill slit length & 2.1 & 2.2 & 2.3 & 2.1 \\
\hline Head height & 5.4 & 7.5 & 5.1 & 7.6 \\
\hline Head width & 12.1 & 11.3 & 11.1 & 12.8 \\
\hline Trunk height & 11.4 & 12 & 8.8 & 10.8 \\
\hline Trunk width & 10.6 & 10.3 & 9.6 & 10.4 \\
\hline Girth & 36.3 & 32.7 & 22 & 32 \\
\hline Pectoral fin length & 11.5 & 12.7 & 10 & 11.2 \\
\hline Pectoral fin base length & 5.1 & 5.1 & 4.8 & 4.8 \\
\hline Pectoral fin height & 5.7 & 5.5 & 5 & 4 \\
\hline Pelvic fin length & 11 & 10 & 13.3 & 8 \\
\hline Pelvic fin base length & 3 & 2.7 & 2.5 & 2.6 \\
\hline Pelvic fin height & 5.4 & 4.8 & 4.4 & 2.4 \\
\hline First dorsal fin length & 9 & 9.3 & 9.2 & 7.6 \\
\hline First dorsal fin base length & 4.8 & 5.5 & 5.1 & 4.4 \\
\hline First dorsal fin height & 3 & 3 & 3.7 & 3.6 \\
\hline Second dorsal fin length & 7.6 & 9.1 & 8.1 & 8 \\
\hline Second dorsal fin base length & 7.2 & 6.8 & 7.7 & 6.8 \\
\hline Second dorsal fin height & 5.1 & 5.1 & 4.8 & 3.6 \\
\hline Dorsal caudal fin margin & 21.8 & 22.7 & 20 & 18.8 \\
\hline Upper tooth counts & 44 & 47 & 46 & 46 \\
\hline Lower tooth counts & 37 & 40 & 40 & 40 \\
\hline
\end{tabular}



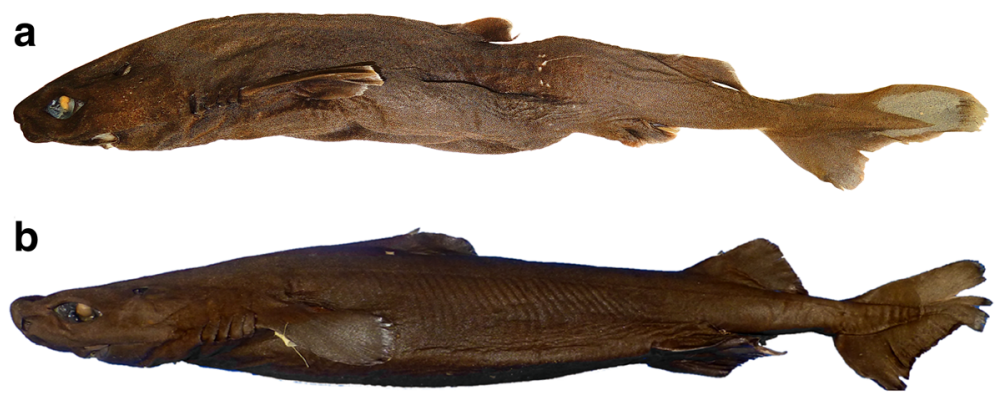

Fig. 3 Lateral view of Zameus squamulosus CNPE-IBUNAM 14608 (a) and Scymnodon ichiharai (b)

ridges on their dermal denticles (Yano \& Tanaka 1984; Taniuchi \& Garrick 1986) (Fig. 2). Specimens are also dark colored and low-flat headed (Head height 5.1-7.6 \% TL) with a short-narrow snout (Preoral length 8.2-9.6 \% TL). Their mouths are nearly transverse and narrow (Mouth wide $6.8-7.7 \% \mathrm{TL}$ ) with well-developed labial furrows (length of upper labial furrow 3-3.6 \%TL and length of lower labial furrow 2-2.4\%TL). Teeth in the lower jaw are large, broad and with knife-shaped cusplets. Teeth in the upper jaw are small and lanceolate, without cusplets (Fig. 1). Both dorsal fins are preceded by a very minute spine. First dorsal fin is long (7.6-9.2 \% TL), narrow at its

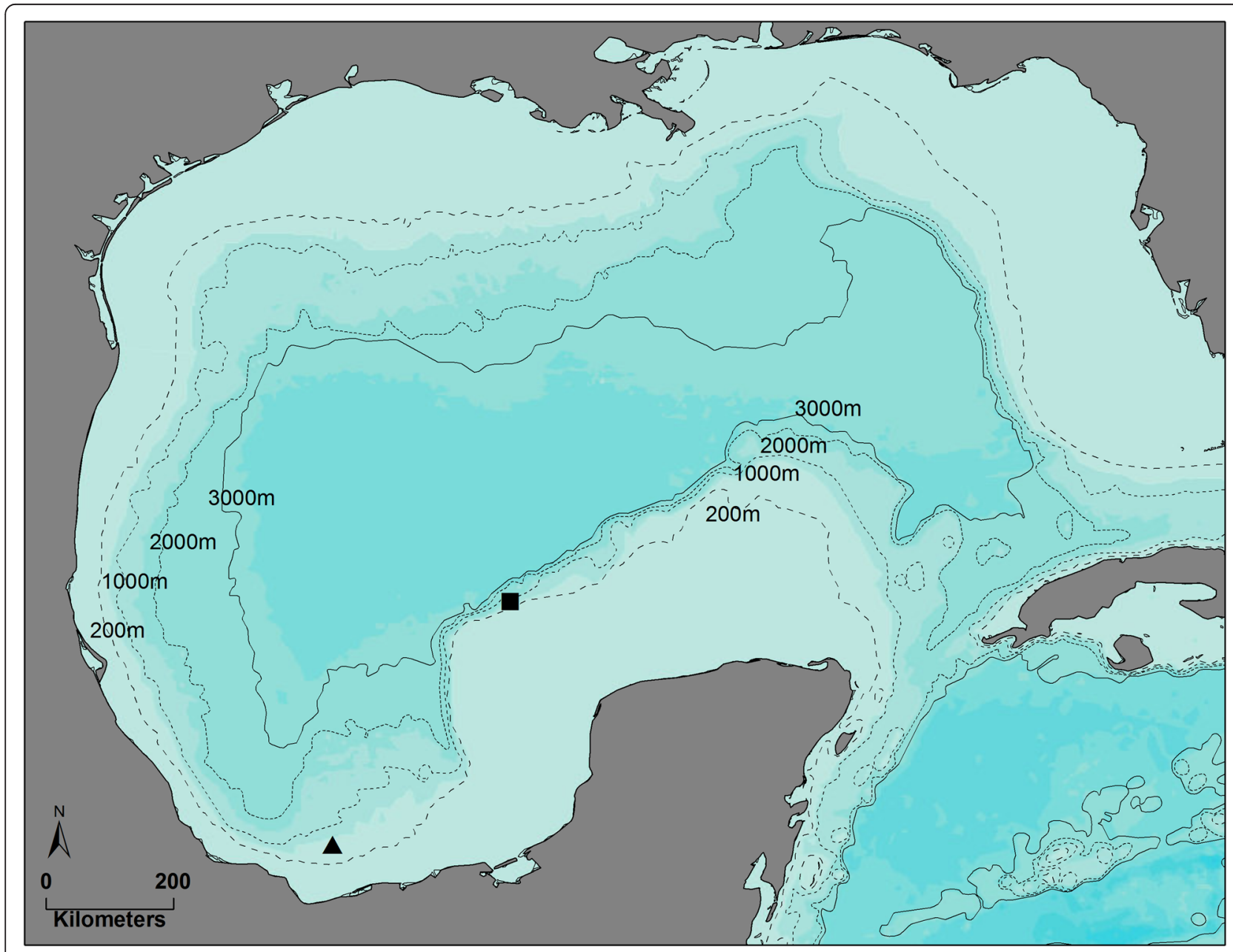

Fig. 4 Locations of the reported specimens of Zameus squamulosus (Square, CNPEIBUNAM 14608; Triangle, CNPE-IBUNAM 16547) 
base (4.4-5.5 \% TL) and inserted posteriorly to the pectoral fin. Second dorsal fin is small (7.6-9.1 \%TL) with a wide base (6.8-7.7 \% TL). Rear tips of the pectoral fins are short and broadly rounded. Anal fin is absent and caudal fin lacks subterminal notch (see Table 1 for complete meristics of the four specimens).

\section{Conclusion}

These are the first confirmed records of Zameus squamulosus in the Southern Gulf of Mexico and therefore increase the number of known shark species in Mexico. Zameus squamulosus has been recorded in catches at midwater trawls (Cadenat \& Blache 1981), on pelagic longlines (Taniuchi 1990; Last \& Stevens 2009) and very close to the surface (Wetherbee \& Crow 1996), but although the specimens reported here were captured in the depth range of the species already described (550-1,450 m), they were collected in a trawl associated to the bottom, which supports the idea of Last \& Stevens (2009) and Wetherbee \& Crow (1996) that this species is more commonly found at the bottom.

\section{Abbreviations}

CNPE-IBUNAM, colección nacional de peces, Instituto Biología, Universidad Nacional Autónoma de México; RV, research vessel; $\mathrm{TL}$, total lenght.

\section{Acknowledgements}

We thank E. Escobar for the invitation to the expeditions, as well as the participants and specimen collectors on the cruise. Ship time of the research cruise Sigsbee VII and COBERPES III carried out onboard the RV 'Justo Sierra' was funded by Universidad Nacional Autónoma de México.

\section{Authors' contributions}

EV identified, determined and measured the specimens, elaborated the illustrations and drafted the manuscript. AM performed the map elaboration and participated in the measurement of the specimens and writting of the publication. $\mathrm{CL}$ participated in the measurement of the specimens and writting of the publication. HE participated in the writting of the publication and coordination of the manuscript. All authors read and approved the final manuscript.

\section{Competing interests}

The authors declare that they have no competing interests.

Received: 16 May 2016 Accepted: 3 June 2016

Published online: 15 July 2016

\section{References}

Akhilesh KV, Bineesh KK, Ganga U, Pillai NGK. Report of velvet dogfish, Zameus squamulosus (Günther, 1877) (Somniosidae: Squaliformes) from Indian waters. Indian Journal of Fisheries. 2013:60:127-129.

Barbosa du Bocage JV, de Brito Capello F. Sur quelques espèces inédites de Squalidae de la tribu Acanthiana, Gray, qui fréquentent les côtes du Portugal. Proc Zool Soc London 1864;(pt 2):260-263.

Bigelow HB, Schroeder WC. A study of the sharks of the suborder Squaloidea. Bulletin of the Museum of Comparative Zoology at Harvard College. 1957; 117:1-150.

Castro Jl. The Sharks of North America. United States of America: Oxford University Press; 2011.

Cadenat J, Blache J. Requins de Mediterranee et d' Atlantique (plus particulierement de la Cote Occidentale d' Afrique). Faune Tropicale. 1981;21:1-330.

Compagno LJV, Dando M, Fowler S. A field guide to the sharks of the world. London: Harper Collins Publishers. 2005. pp. 368.
Ebert DA, Fowler S, Compagno L. Sharks of the World a Fully Illustrated Guide. Plympton St. Maurice, United Kingdom: Wild Nature Press; 2013.

Ebert DA, Stehmann MFW. Sharks, Batoids and Chimaeras of the North Atlantic FAO species catalogue for fishery purposes. No. 7. Roma: FAO; 2013.

Ebert DA, Knuckey JDS, Kamikawa DJ. First eastern North Pacific record of the velvet dogfish, Zameus squamulosus (Chondrichthyes: Squaliformes: Somniosidae). Mar Biodivers Rec. 2014;7:e48.

Günther A. Preliminary notes on new fishes collected in Japan during the expedition of H. M. S. Challenger. Ann Mag Nat Hist. 1877;20:433-46.

Jordan DS and Fowler HW. A review of the elasmobranchiate fishes of Japan. Proceedings of the United States National Museum. 1903;26:593-674.

Last PR, Stevens JD. Sharks and Rays of Australia. 2nd ed. Australia: CSIRO; 2009.

McEachran JD, Fechhelm JD. Fishes of the Gulf of Mexico. Volume 1: Myxiniformes to Gasterosteiformes. Austin: University of Texas Press; 1998.

Naylor GJP, Caira JN, Jensen K, Rosana KAM, White WT, Last PR. A DNA sequencebased approach to the identification of shark and ray species and its implications for global elasmobranch diversity and parasitology. Bull Am Mus Nat Hist. 2012;367:1-263.

Taniuchi T. The role of elasmobranchs in Japanese fisheries. In H. L. Pratt, Jr., S. H. Gruber and T. Taniuchi, (eds). Elasmobranchs as fishing resources: advances in the biology, ecology, systematics, and the status of the fisheries. NOAA Technical Report. NMFS. 1990;90:415-426

Taniuchi T, Garrick JAF. A new species of Scymnodalatias from the Southern Oceans, and comments on other squaliform sharks. Japanese J Ichthyology. 1986;33: 119-34.

Wetherbee BM, Crow GL. First record of the squaloid shark Scymnodon squamulosus from the Hawaiian Islands. Ichthyological Res. 1996;43:334-9.

White WT, Vaz DF, Ho HC, Ebert DA, de Carvalho MR, Corrigan S, et al. Redescription of Scymnodon ichiharai Yano and Tanaka 1984 (Squaliformes: Somniosidae) from the western North Pacific, with comments on the definition of somniosid genera. Ichthyological Res. 2014;62:213-29.

Yano K, Tanaka S. Review of the deep sea squaloid shark genus Scymnodon of Japan, with a description of a new species. Japanese J Ichthyology. 1984;30:341-60.
Submit your next manuscript to BioMed Central and we will help you at every step:

- We accept pre-submission inquiries

- Our selector tool helps you to find the most relevant journal

- We provide round the clock customer support

- Convenient online submission

- Thorough peer review

- Inclusion in PubMed and all major indexing services

- Maximum visibility for your research

Submit your manuscript at www.biomedcentral.com/submit
C Biomed Central 